\title{
MEANS OF EXPRESSING MODALITY IN KOREAN LANGUAGE (ON THE EXAMPLE OF DUTY)
}

\section{Amira Muminovna Azimova}

Uzbek State University Of World Languages Scientific Adviser: Professor Kim Natalya Dek-Xenovna Tashkent, Uzbekistan

\section{ABSTRACT}

The article is devoted to the peculiarities of the expression of modal features in the form of obligation. Due to the variety of approaches to the phenomenon under consideration, the topic of this article seems to be relevant in the Korean language. The study of these differences helps to identify systemic differences in the means of expressing modality in different languages, including Russian.

KEYWORDS: - Modality, category of modality, characteristic of modality, obligation, modality of the Korean sentence.

\section{INTRODUCTION}

Studying the Korean language in Uzbekistan continues to be very popular. The communicative orientation of teaching the Korean language is especially noted and, accordingly, interest in modal meanings is justified by the fact that their use causes ambiguous answers.

As is known, the lexical and grammatical elements of the language are the means of expressing the category of modality. It should be noted that in the well-known works on the grammar of the Korean language, this category is separately distinguished by A.A. Kholodovich ${ }^{1}$, in others it is limited only to the enumeration of modal words that are

${ }^{1}$ A.A. Kholodovich An outline of the grammar of the Korean language. - M: Literature in foreign languages, 1954. - $320 \mathrm{p}$. considered adverbs ${ }^{2}$. According to A.A. Kholodovich, there are five analytical structures that express the category of obligation:

- adverb preceding the main verb + particle 야 + service verb 하다:

우리가 학교 숙제를 열심히 해야 한다.

We have to do school assignments.

동생은 자주 연습을 해야 하는데 안 해요.

The little brother has to exercise often, but he doesn't.

- verb preceding the main verb + particle 야 + suffix 겠 followed by the predicate:

이 것은 시간이 걸리는 문제라서 나중에 생각해야겠다.

This task takes time, you will have to think about it later.

우리가 이젠 이런 일이 없도록 꼭 확인해야겠다.

2 Ramstedt G. Grammar of the Korean Language 1951. - $232 \mathrm{p}$. 
CURRENT RESEARCH JOURNAL OF PHILOLOGICAL SCIENCES 2(11):

56-59, November 2021

DOI: https://doi.org/10.37547/philological-crjps-02-11-14

ISSN 2767-3758

(C2021 Master Journals

Crossref doi

gil Google

Accepted25 $5^{\text {th }}$ November, 2021 \& Published 30 th November, 2021

To prevent this from happening again, it will be necessary to check everything.

- adverb preceding the main verb + 야 + service verb 되다:

여러분, 이 상은 우리가 받아야 됩니다.

Gentlemen, you need to take these prizes.

이 것은 보내야 되는 게 아니야?

Shouldn't it have been sent.

-the participle of the future tense with the modal meaning of obligation; conditional participle from the negative form of the verb + negative form of the verb 되다 with the construction formula 하지 아니 하면 아니 되다, for example:

오늘 꼭 가야 합니다. 안 가면 안 돼요.

You should definitely go today. It is impossible not to go.

이렇게 잘 보지 않으면 안 됩니다. 계속 문제만 생길겁니다.

You don't have to look that good. Problems will continue.

Based on the foregoing, when describing the means of expressing modality in the Korean language, we rely on the systematization proposed by A.A. Kholodovich, since it is the most adequate. First, the systematic approach made it possible to see the most strikingly distinctive features of linguistic elements, in this case - constructions and grammatical elements expressing modality in each of the languages under consideration. Secondly, it made it possible to identify systemic differences in the means of expressing modality in two differentstructured languages - Korean and Russian. It is these differences that create difficulties in translating Korean modal constructions into Russian. The considered categorical modal meaning of the action of the obligation expresses the prescription predetermined by laws, customs, traditions, rules, obligations, instructions, internal needs or personal experience of the speaker by the usual sequence of events, that is, by norms in the broad sense of the word $^{3}$. Obligation is a characteristic of practical action from the point of view of a certain system of norms ${ }^{4}$.

As you know, in the Korean language, as in the language of the agglutinative type, the obligation is conveyed not so much by lexical as by grammatical and lexical-grammatical constructions, which can be simple and complex. Below is an example where lexical units with the meaning "duty, responsibility, obligation, duty" are used to express a duty with the meaning "must". And also, an example of the use of lexical units with the meaning of "duty, obligation" 책무, 의무.

어른을 잘 섬기는 것은 아이의 책무입니다.

It is the responsibility of children to honor elders. $\rightarrow$ Children should honor their elders.

자식을 잘 키우는 것은 부모의 의무입니다.

It is a parent's duty / responsibility to bring up children well. $\rightarrow$ Parents should bring up their children well.

A simple syntactic construction using lexical units such as 책무, 의무, 책임 with the meaning "obligation", "responsibility" in combination with the predicative 있다 / 없다, the verb 지다 "take responsibility, bear", where the modal construction is 의무 / 책임 이 있다 / 없다 governs a propositional verb in participle form in - ㄹ / 을.

Thus, the construction - ㄹ / 을 의무 / 책임 이 있다 / 없다 describe a modal situation like "A must / must do B".

아버지는 일할 의무가 있습니다.

The father must to work.

모든 회사들이 납세의 의무를 집니다.

All companies must pay taxes.

Along with the fact that in such a syntactic construction it is possible to replace the predicative,

\footnotetext{
${ }^{3}$ I. G. Osetrov Structural varieties of a simple sentence with the modal meaning of obligation. dis. Cand. philol. sciences. - M. 1984.

${ }^{4}$ https://ru.wikipedia.org
} 
CURRENT RESEARCH JOURNAL OF PHILOLOGICAL SCIENCES 2(11):

56-59, November 2021

DOI: https://doi.org/10.37547/philological-crjps-02-11-14

ISSN 2767-3758

(C2021 Master Journals

\section{Crossref do) 81 Google}

Accepted $25^{\text {th }}$ November, 2021 \& Published $30^{\text {th }}$ November, 2021

it is also possible to replace the lexical unit 의무 with other names, for example, a name belonging to the subclass of autonomous 필요 "necessity". The construction will look like - ㄹ / 을 필요 가 있다 / 없다, or like - 이 / 가 필요 하다 and will be translated into Russian as "necessary, necessary", for example:

이 집은 수리할 필요가 있다.

This house needs to be renovated Or

아이의 언어 발달이 어떤지 정확한 평가가 필요하다.

An accurate assessment of the development of the child's speech is required.

Above, examples of expressions were considered, which in their form are simple syntactic constructions, using lexical (nominal and verb) elements with a minimum degree of grammaticalization.

The second group of constructions is much more often used to express the obligation in the Korean language - these are constructions with a high degree of complexity.

Main verb + 아 / 어 + 야 + auxiliary verb + ending. In this construction, - 야 is a modal suffix that is used with 하다 / 되다 as a construct predicate. Constructions - 아야 하다 / 되다 in modern Korean expresses the need to perform an action. 이사 문제는 아내와 의논해야 한다.

The question of moving should be discussed with my wife.

너는 지금 떠나야 한다.

You have to leave now.

It should be noted that the construction - 아야 하다 is often used with the suffix - 겠 in the abbreviated form - 아야 겠다, where the suffix - 겠 introduces an additional connotation of "forced necessity" and is rendered into Russian as "must", "must"; used with the indicator of the past tense - 았 / 었어 야 했다; with a restrictive particle - 만, 아야만 하다. 이사 문제는 아내와 의논해야겠다.
The question of the move I will have (will have to) discuss with my wife.

이사 문제는 아내와 의논했어야 했다.

I had to discuss the issue of moving with my wife. 이사 문제는 아내와 의논했어야만 했다.

I had to discuss the issue of moving with my wife.

The second most common form of expression of obligation, although it is used less often than the above construction, is the construction "main verb + 지 않 + conditional particle 으면 + 안 [an] + 되다 지 않으면 안되다. This construction consists of a negation construction - 지 않다, a conditional suffix - (으) 면 with the meaning "if". This construction is governed by the auxiliary verb 되다 with negation 안.

As a result, the double negation in this construction conveys the meaning of "must". Semantically, this construction expresses a lesser degree of "obligation" in comparison with - 야 하다, which in translation into Russian can be conveyed through the predicate "necessary, necessary" instead of "must, must".

나는 공부하지 않으면 안 된다.

I cannot fail to study. $\rightarrow$ I need to study.

Next, we will consider the third group of structures for the transfer of obligation. Constructions using the service name ㅅ․

It is known that the modal operator 수 있다 / 없다 is used with the meaning of "possibility and impossibility" to perform any action.

However, the name 수 can also be found in constructs with the meaning of obligation - 지 않을 수 없다 / - 수 밖에 없다, where the modal operator of negation of the possibility is used - 수 없다 and the additional negation is 지 않을, 밖에 with the meaning "outside, outside". 나는 그것을 하지 않을 수 없다.

I had to do it (compelled).

나는 그렇게 할 수 밖에 없다.

I have to (must) do so. 
CURRENT RESEARCH JOURNAL OF PHILOLOGICAL SCIENCES 2(11):

56-59, November 2021

DOI: https://doi.org/10.37547/philological-crjps-02-11-14

ISSN 2767-3758

(C)2021 Master Journals

crossref do) 8: Google

Accepted25 $5^{\text {th }}$ November, 2021 \& Published 30th November, 2021

As can be seen from the examples above, in both cases, these constructions add an additional shade of the obligatory need to perform an action, excluding other possibilities, and is transmitted into Russian as "forced, must". In addition, lexical means are also used to express the reinforcement of the meaning of obligation, namely, such modal words / adverbs as: 꼭 "necessarily", 반드시 "certainly", 당 연히 "naturally", etc.

Thus, modal meanings leave a wide range of issues requiring in-depth study. As noted above, a systematic approach is required to study the issues of modality and modal meanings in Korean. In addition, the study of the similarities and differences of certain grammatical expressions of modality creates an opportunity to consider the categorical modal meaning of the action of obligation, expressing the prescription of predetermined laws, customs, traditions, etc.

\section{ReFERENCES}

1. Adamets $P$ To the question of modifications (modal transformations) with the meaning of necessity and possibility. - M. 1968.

2. Alieva E.N. Functional-semantic category of modality and its implementation in differentstructured languages (Russian, English, Lezgi): Author's abstract. dis. ... doc. philol. sciences / Alieva E.N .; M., 2010.

3. Kim N.D. The nature of the naming and communicative functions of a sentence in the Korean language. Oriental studies, Tashkent State Institute of Culture, No. 1. - Tashkent, 2005.

4. Ramstedt G. Grammar of the Korean language (translated from English and notes by AA Kholodovich, under the editorship and editorship of prof. Pashkov BK) M .: Foreign literature. 1951.

5. Sturgeon I.G. Structural varieties of a simple sentence with the modal meaning of duty. dis. Cand. philol. sciences. - M. 1984.

6. Kholodovich A.A. An outline of the grammar of the Korean language. - M: Literature in foreign languages, 1954.

7. Rasuljanovna, I. N. (2020). The verbal lacunas in chinese and uzbeklanguages (on the example of grammatical and somatic lacunas). ACADEMICIA: An International Multidisciplinary Research Journal, 10(5), 1961700. 